\title{
Mechanisms of Chronic Central Neuropathic Pain after Spinal Cord Injury
}

\author{
Claire E. Hulsebosch ${ }^{\mathrm{a}}$, Bryan C. Hains ${ }^{\mathrm{b}}$, Eric D. Crown ${ }^{\mathrm{c}}$, and Susan M. Carlton ${ }^{\mathrm{a}}$ \\ aDepartment of Neuroscience and Cell Biology, University of Texas Medical Branch, Galveston, TX \\ 77555-1043, USA \\ b Department of Neurology, Yale University School of Medicine, West Haven, CT. 06516 \\ cPain Research, Merck Research Laboratories, West Point, PA 19486
}

\section{Abstract}

Not all spinal contusions result in mechanical allodynia, in which non-noxious stimuli become noxious. The studies presented use the NYU impactor at $12.5 \mathrm{~mm}$ drop or the Infinite Horizons Impactor (150 kdyne, $1 \mathrm{sec}$ dwell) devices to model spinal cord injury (SCI). Both of these devices and injury parameters, if done correctly, will result in animals with above level (forelimb), at level (trunk) and below level (hindlimb) mechanical allodynia that model the changes in evoked somatosensation experienced by the majority of people with SCI. The sections are as follows: 1) Mechanisms of Remote Microglial Activation and Pain Signaling in "Below-Level" Central Pain 2) Intracellular Signaling Mechanisms in Central Sensitization in "At-Level" Pain 3) Peripheral Sensitization Contributes to "Above Level" Injury Pain Following Spinal Cord Injury and 4) Role of Reactive Oxygen Species in Central Sensitization in Regional Neuropathic Pain Following SCI. To summarize, differential regional mechanisms contribute to the regional chronic pain states. We propose the importance of understanding the mechanisms in the differential regional pain syndromes after SCI in the chronic condition. Targeting regional mechanisms will be of enormous benefit to the SCI population that suffer chronic pain, and will contribute to better treatment strategies for other chronic pain syndromes.

\section{Keywords}

Reactive Oxygen Species; cytokines; Central Sensitization; Peripheral Sensitization; Pain; Chronic Pain; Regional Pain Syndrome

\section{Introduction}

\section{Chronic Pain and Spinal Cord Injury}

Spinal cord injury (SCI) is a devastating event that results in motor dysfunction below the level of lesion, as well as the development of chronic pain syndromes. There are approximately 400,000 spinally-injured patients in the U.S. with over 14,000 new injuries occurring each year (Sekhon and Fehlings, 2001). In both complete and partial spinal lesions, chronic pain develops

Corresponding author: Claire E. Hulsebosch, Ph.D., Department of Neuroscience and Cell Biology, University of Texas Medical Branch, 301 University Boulevard, Galveston, TX 77555-1043, (409) 772-2939, (409) 772-3222 fax, cehulseb@utmb.edu.

Publisher's Disclaimer: This is a PDF file of an unedited manuscript that has been accepted for publication. As a service to our customers we are providing this early version of the manuscript. The manuscript will undergo copyediting, typesetting, and review of the resulting proof before it is published in its final citable form. Please note that during the production process errors may be discovered which could affect the content, and all legal disclaimers that apply to the journal pertain. 
within months following injury (Richards et al., 1980). Up to $80 \%$ of patients experience clinically significant pain which is described as burning, stabbing, and/or electric-like (Finnerup et al., 2001; Siddall et al., 2003). Post-SCI pain can produce drastic impairments in daily routines and quality of life to a greater extent than motor impairment (Rintala et al., 1998), and is refractory to clinical treatments despite a variety of neurosurgical,

pharmacological, and behavioral therapeutic strategies (Balazy, 1992; Turner et al., 2001). The pain so greatly affects the quality of life that depression and suicide frequently result (Cairns et al., 1996; Segatore, 1994).

The pain syndromes are permanent and, because the lesions are central, are referred to as central neuropathic pain (CNP). Research focused on improving recovery of function, including the reduction of CNP, is essential. The pain syndromes or dysesthesias (disturbing somatic sensations that may not be painful) can be divided into two broad categories based upon their dependency or independence of peripheral stimuli: 1) spontaneous pain - which occurs independently of peripheral stimuli, is persistent, waxes and wanes intermittently, and is described as numbness, burning, cutting, piercing or electric-like (Davidoff and Roth, 1991); 2) peripherally evoked pain - which occurs in response to either normally nonnoxious or noxious stimuli. In addition, some chronic spinal cord injured patients experience a band or "girdle" of hyperpathia and/or allodynia at the level of the sensory loss (Tasker and Dostrovsky, 1989). Siddall and colleagues (2002) defined three regions of pain that result from SCI: 1) above-level pain which occurs at dermatomes cranial to the injury site, 2) at-level pain which occurs in dermatomes near the spinal injury, develops shortly after SCI, where the pain is often characterized as either stabbing or is a stimulus-independent type that is accompanied by allodynia, and 3) below-level pain, which is localized to dermatomes distal to the injury site, develops more gradually than at-level pain, and is often classified as a stimulus independent continuous burning pain (Sjolund 2002; Vierck Jr et al. 2000). We have experience testing evoked pain and have pioneered methods for measuring spontaneous pain in animals (Hulsebosch et al., 2000; Mills, et al., 2001a).

\section{Modeling Central Neuropathic Pain}

Little attention has been given to mechanisms of chronic pain in SCI in the clinics, and it has only been in the last several years that animal models were developed to study the development and maintenance of CNP-like behavior after SCI. The models include an intravascular photochemical reaction that occludes blood vessels, producing spinal cord ischemia with subsequent trunk mechanical allodynia (Hao et al., 1991; Xu et al., 1992); anterolateral lesions of the spinal cord in monkeys and rats that produce overgrooming and mechanical allodynia (Ovelmen-Levitt, et al., 1995; Vierck and Light, 2000); a clip compression model in which the thoracic spinal cord is compressed by a $35 \mathrm{~g}$ or $50 \mathrm{~g}$ clip that results in mechanical hyperalgesia in the hindlimbs (Bruce et al., 2002); quisqualic acid injection (an AMPA/kainate and metabotropic receptor agonist) into the dorsal horn that produces overgrooming (Yezierski, et al., 1998); a spinal hemisection model of CNP (Christensen et al., 1996; Christensen and Hulsebosch, 1997; Gwak et al., 2008); and a spinal contusion model, in which mechanical allodynia "girdles" the trunk (Siddall et. al., 1995; Lindsey, et al., 2000; Hulsebosch, et al., 2000). We have further characterized this last model, demonstrating the presence of mechanical and thermal allodynia in both forelimbs (above level), "girdling" (at level) and in both hindlimbs (below level) (Hulsebosch et al., 2000). The spinal contusion model best parallels the injury profile described in human spinal cord injury (Bunge et al., 1993; Bunge, 1994).

The following four sections focus on mechanisms of central neuropathic pain in the spinal contusion model in the rat. Not all spinal contusions result in mechanical allodynia (i.e., the phenomenon in which non-noxious stimuli become noxious). The studies presented use the NYU impactor at $12.5 \mathrm{~mm}$ drop or the Infinite Horizons Impactor (150 kdyne, $1 \mathrm{sec}$ dwell). 
Both of these devices and injury parameters, if done correctly, will result in animals with above level (forelimb), at level (trunk) and below level (hindlimb) mechanical allodynia that model the changes in evoked somatosensation experienced by the majority of people with SCI. The sections are as follows: 1) Mechanisms of Remote Microglial Activation and Pain Signaling in "Below-Level" Central Pain (Bryan C. Hains); 2) Intracellular Signaling Mechanisms in Central Sensitization in "At-Level" Pain (Eric D. Crown); 3) Peripheral Sensitization Contributes to "Above Level" Injury Pain Following Spinal Cord Injury (Susan M. Carlton) and 4) Role of Reactive Oxygen Species in Central Sensitization in Regional Neuropathic Pain Following SCI (Claire E. Hulsebosch).

\section{Mechanisms of Remote Microglial Activation and Pain Signaling in "Below- Level" Central Pain}

\section{Doral Horn Neuron Hyperexcitability and Central Sensitization}

After SCI, when the quality of a peripheral stimulus does not change, central mechanisms must account for the observed enhancements in nociceptive processing of dorsal horn neurons (but see below). SCI results in sustained hyperexcitability of these neurons, the majority of which comprise the spinothalamic tract (STT). Extracellular recordings from the dorsal horn in various models of acute and chronic SCI reveal changes in electrophysiologic properties (Hao et al., 1992; Yezierski and Park, 1993; Drew et al., 2001; Hains et al., 2003a, b; Hains and Waxman, 2006; Lampert et al., 2006) including shifts in proportions of neurons responding to noxious stimulation, increased and irregular spontaneous background activity, increased evoked activity to (formerly) innocuous and noxious stimuli, and alterations in sodium currents. Observations in rodent models are analogous to the abnormal functional characteristics of spinal neurons in SCI patients with chronic pain (Loeser et al., 1968).

\section{Microglial Activation and Pain Modulation after SCI}

Until very recently, pain resulting from injury to the nervous system was thought to arise primarily from the dysfunction of neurons. However, recent evidence indicates that alterations in the neuroimmune system also contribute to chronic pain. A unique class of neuroimmune cells called microglia, which normally exist in a resting but sensing state, shift their status and undergo transformation to more reactive (or "alerted" or "activated") states in response to pathology or injury (Hanisch and Kettenmann, 2007). Microglia are implicated in the initiation phase of peripheral injury-induced pain (Coyle, 1998; Fu et al., 1999; Watkins et al., 2001; Jin et al., 2003; Ledeboer et al., 2005; DeLeo et al., 2006; Watkins et al., 2007), and are activated via local release of factors such as IL-6, ATP, substance P, CCL2, and fractalkine (Ji and Strichartz, 2004; Marchand et al., 2005; Wieseler-Frank et al., 2005; Moalem and Tracey, 2006).

Microglia are also chronically activated in the spinal cord after clinical (Schmitt et al., 2000; Chang, 2006) and experimental SCI (Hains et al., 2003c; Sroga et al., 2003; Nesic et al., 2005; Zai and Wrathall, 2005; Crown et al., 2006; Hains and Waxman, 2006; McKay et al., 2007; Zhao et al., 2007a). We recently showed that there is a dramatic shift in microglial status from a resting to an activated state in the lumbar spinal cord after SCI at a time when dorsal horn nociceptive neurons fire at very high rates in response to stimulation of peripheral receptive fields of the skin, and pain-related behaviors such as mechanical allodynia and thermal hyperalgesia are evident (Hains et al., 2003c; Hains and Waxman, 2006). Selective pharmacological inhibition of microglial activation and signaling results in a return to the resting morphological phenotype as well as reductions in electrophysiologic and behavioral concomitants of pain (Hains and Waxman, 2006; Zhao et al., 2007a,b). We recently identified a mechanism by which microglia activated after SCI utilize $\mathrm{PGE}_{2}$ as a signaling molecule to induce dorsal horn sensory neurons to undergo changes in excitability that underlies chronic 
pain (Zhao et al., 2007a). We further demonstrated that within activated microglia, $\mathrm{PGE}_{2}$ production and release is regulated by pERK1/2 MAP kinase (Zhao et al., 2007a). This is mechanistically different than from peripheral nerve injury where microglia play a role in the initiation phase of pain.

\section{CCL21 as a Novel Modulator of Microglial Activation}

Rapid morphological transformation and homing of microglia to sites of injury is induced by locally upregulated chemokines (Streit et al., 1999; Columba-Cabezas et al., 2003; Carbonell et al., 2005; Kurpius et al., 2006). Chemokines activate specific receptors on microglia to trigger activation (White et al., 2005a; Watkins et al., 2007). Our data identifies a new neuronmicroglia signaling mechanism involving the cysteine-cysteine chemokine ligand 21 (CCL21, Exodus-2, 6Ckine) which is upregulated after nervous system injury. Until now, only fractalkine (CX3CL1) and CCL2 (MCP-1) have been implicated in microglial activation. Fractalkine is a potent microglial modulator after peripheral nerve injury and contributes to the induction phase of pain (Milligan et al., 2004; Verge et al. 2004). CCL2 is upregulated in damaged dorsal root ganglion neurons (White et al., 2005b), and is transported to sensory terminals in the spinal cord where it activates microglia (Zhang and DeKoninck, 2006).

CCL21 elicits a chemotaxic response by microglia but not monocytes or neutrophils (Gunn et al., 1999), that can be disrupted in CCL21 receptor knock-out mice (Rappert et al., 2004). Diffusible CCL21 binds and activates the CCR7 and CXCR3 receptors expressed by microglia (Soto et al., 1998; Dijkstra et al., 2006). Microglia activated by LPS stimulation in vitro (Dijkstra et al., 2006), in MS lesions (Serafini et al., 2006), and in models of EAE during symptom onset and progression (Columba-Cabezas et al., 2003; Dijkstra et al., 2006), upregulate the CCR7 receptor. Microglia respond to CCL21 via lower-affinity activation of the CXCR3 receptor (Murphy et al., 2000; Rappert et al., 2002; Dijkstra et al., 2004). As in the thalamus after SCI (Zhao et al., 2007b), intraspinal injections of recombinant CCL21 robustly elicits microglial activation, neuronal hyperexcitability, and mechanical allodynia. Additionally, CCL21 neutralization reverses these pain-related phenomena after SCI.

\section{CCL21 Induction by Massive Glutamate Release after SCI}

Both CCL21 upregulation and release are observed in an in vitro model of neuronal injury where neurons are exposed to high concentrations of glutamate (de Jong et al., 2005). In rodents, SCI leads to dramatic (up to 50-fold) increases in local and regional (up to $5 \mathrm{~mm}$ away from the injury site) tissue levels of the excitatory amino acids glutamate and aspartate (Liu et al., 1999; McAdoo et al., 1999). This region encompasses the ventrolateral quadrant of the spinal cord that contains the STT. The STT carries nociceptive information supraspinally. CCL21 could thus be upregulated in the cell bodies of STT neurons whose axons have been damaged by injury-associated events after SCI. Indeed, CCL21 is synthesized by damaged nociceptive neurons in response to high levels of excitatory amino acid release after SCI, and distal release of CCL21 triggers microglial activation at spinal segments far from the site of injury. Similar microglial responsiveness to damaged neurons is observed during neurodegeneration (Sørensen et al., 1996; Vela et al., 2002). Levels of CCL21, a potent microglial activator, are dramatically increased in the lumbar enlargement as a result of thoracic SCI. It is likely that CCL21 is acting as a remote modulator and/or trigger of microglial activation. In this case, the axons of STT neurons that originate in the lumbar enlargement are damaged as they pass by the SCI site, triggering CCL21 upregulation and release at the cell bodies in the lumbar enlargement. 


\section{Intracellular Signaling Mechanisms in Central Sensitization in At-Level Pain}

Research involving the examination of below level pain has lead to the elucidation of a number of mechanisms that may contribute to the development and maintenance of chronic pain including: 1) increased sensitivity due to loss of nerve input (Nakata et al. 1979; Wright and Roberts 1978); 2) removal of inhibitory influences (Devor and Wall 1981; Hains et al. 2002; Lombard et al. 1979); 3) increased efficacy of previously ineffective synapses (Basbaum and Wall 1976; Devor and Wall 1981); 4) deafferentation hyperexcitability of spinal and/or thalamic neurons (Lenz et al. 1994; Rinaldi et al. 1991); 5) development of abnormal ion channels that alter the membrane properties of pain cells (Waxman 2001); 6) alterations in transporter distribution and activity, such as the SCI-induced reversal of glutamate transporters that leads to increases in extracellular glutamate (Vera-Portocarrero et al. 2002) and 7) transmitter and/or receptor plasticity (Hains et al. 2002; Mills and Hulsebosch 2002a). Despite the scientific gains in our understanding of below level pain, research is lacking on the role these mechanisms play in the other categories of neuropathic pain after SCI. We have chosen to focus on at-level pain that occurs rostral to a contusion injury, in the hopes of furthering our understanding and creating better ways to alleviate pain following SCI. This aim has been supported by the recent development of a model (Hulsebosch et al. 2000; Lindsey et al. 2000 ) in which rats given a contusion injury develop at-level mechanical allodynia by 30 days after injury.

Recent research suggests neuropathic pain that develops after peripheral injury (e.g., capsaicin injection, formalin injection, or sciatic nerve injury) is a result of central sensitization. Central sensitization refers to persistent hyperexcitability observed in dorsal horn neurons after insult and shares a number of molecular similarities with the phenomenon of long-term potentiation (a phenomenon believed by many to underlie the synaptic changes associated with learning and memory). For example, both phenomena have an early activity-dependent phase that alters neuronal excitability through synaptic strengthening and a later transcription-dependent phase that relies on the formation of new proteins (Ji et al. 2002, ${ }^{2003}$; Nguyen and Kandel 1996). In addition, both the late phase of hippocampal LTP and transcription-dependent central sensitization have been linked to initial activation of the NMDA receptor, followed by subsequent activation of downstream intracellular enzymatic cascades involving adenylyl cyclase, PKA, PKC, and/or CaMK (Roberson et al. 1999). During both phenomena, these cascades can also be induced by intracellular increases in calcium, cAMP, nerve growth factor, nitric oxide, or CaMKII (Ginty et al. 1994; Impey et al. 1999; Sheng et al. 1991; Sweatt 2001; Roberson et al. 1999). Activation of these cascades leads to activation (via phosphorylation) of a number of MAPKs, including extracellular signal related kinase (ERK) 1/2, c-Jun N terminal kinase (JNK), and p38 MAPK which then, in turn, can lead to phosphorylation of transcription factors such as cyclic AMP responsive element binding protein (CREB) and changes in gene transcription (Lonze and Ginty 2002). Whereas evidence exists for changes in expression of long-term potentiation related mitogen-activated protein (MAP) kinases and transcription factors following peripheral injury (for review, see Ji and Woolf 2001 and Ji and Suter 2007), this hypothesis has yet to be tested rigorously in a model for chronic central pain and SCI. It is well known that SCI causes an increase in excitatory amino acid concentrations that lead to increases in intracellular calcium levels (Faden and Simon 1988; Liu et al. 1991; McAdoo et al. 1999; Tator and Fehlings 1991). Given these and other data, our hypothesis was that increases in intracellular calcium levels could trigger the activation of a number of cell signaling cascades that cause the development and contribute to the maintenance of at-level neuropathic pain.

Our first goal in testing this hypothesis was to establish that central neuropathic pain following spinal cord injury was related to increased activation of intracellular signaling kinases and 
transcription factors that are associated with central sensitization. To accomplish this goal, Sprague-Dawley rats were given a contusive spinal cord injury at thoracic level T10 and then monitored weekly for the development of at-level neuropathic pain. The model we developed to study at-level neuropathic pain involves the application of von Frey filaments to the rat's back in the region at and around the site of injury. Using this model, changes in the percentage of vocalization responses to the application of force were used as the primary measure of the development of at-level neuropathic pain. In our first study using this paradigm (Crown et al 2005), we found that rats given moderate contusion injury (12.5 mm drop using the NYU impactor) developed at-level neuropathic pain by 35 days post injury. This neuropathic pain was not evident until at least 14 days post injury. After testing the rats at 35 days post injury, spinal cord tissue was taken from the site of injury to examine changes in the activation state of the transcription factor CREB at the level of the injury. Compared to sham and naïve rats, SCI rats were found to have significant increases in the expression of the activated form of CREB (pCREB). This activation was seen throughout the thoracic spinal cord and also was found to occur within spinothalamic tract cells in the thoracic dorsal horn.

The next research question we sought to answer was whether increased pCREB activation was a general result of spinal cord injury or whether this increased activation was specific to SCI rats that developed neuropathic pain. As discussed above, not all humans that received a spinal cord injury develop at-level neuropathic pain. This same variability occurs in rodents and is believed to be related to the severity of injury, as more severe spinal cord injuries produce a greater percentage of rats that develop neuropathic pain. Using an injury severity that causes ca. $50 \%$ of rats to develop at-level neuropathic pain, we were able to examine 2 separate populations of rats, those that developed neuropathic pain and those that did not. Spinal cord tissue at and around the site of the contusion injury was taken from rats at 35 days post injury, at a time point when at-level neuropathic pain had been established. As hypothesized, the results from this series of experiments indicated that increased pCREB activation occurred in SCI rats that developed at-level neuropathic pain, whereas SCI rats that failed to develop neuropathic pain were not different than sham or naïve rats (Crown et al 2006). In addition, we also examined whether kinase activation upstream of pCREB activation was increased specifically in SCI rats that developed at-level neuropathic pain. These experiments found that increased activation of ERK1/2, p38 MAPK, and CaMKII (but not JNK) occurred in rats that developed at-level neuropathic pain relative to the other groups. Taken together, these data indicate that persistent activation of intracellular signaling cascades involving MAP kinases and the transcription factor CREB are related to the maintenance of at-level neuropathic pain after SCI (Figure 2). We have recently also begun to use pharmacological tools designed to inhibit the activation of intracellular kinases to examine whether MAP kinase activation is causally related to at-level neuropathic pain. Using the inhibitor of p38 MAP kinase, SB203580, we have shown that inhibiting this kinase can attenuate the expression of at-level neuropathic pain (Crown et al, 2008). Future work will continue to examine the role of different intracellular kinases in the development and maintenance of at-level neuropathic pain.

In summary, the data indicate that activation of MAP kinases and the transcription factor CREB, are important mediators of the intracellular events that lead to the development of persistent hyperexcitability in the dermatomes corresponding to the site of injury. Further work is needed to examine fully the role of these important signaling molecules in at-level neuropathic pain. 


\section{Peripheral Sensitization Contributes to "Above Level” Injury Pain Following Spinal Cord Injury Central Sensitization After SCl}

The hyperexcitability and increased sensitivity of dorsal horn neurons to sensory stimuli (cutaneous, musculoskeletal, visceral, etc) has been referred to as central sensitization (Woolf, 1983; Willis, 1993a; Hulsebosch, 2003). One mechanism by which central sensitization can be achieved in the intact spinal cord is through increased peripheral input, particularly $\mathrm{C}$ input, as seen following capsaicin injection (Willis, 2001), peripheral injury (Woolf, 1993; Ren and Dubner, 1999), or inflammation (Neugebauer et al., 1994). The changes observed in sensitized dorsal horn cells parallel changes observed in pain states, as described in both rodent and primate models of peripheral neuropathy (Palecek et al., 1992a,b), arthritis (Neugebauer et al., 1994) and intradermal capsaicin (Willis, 1993b; Zhou et al., 2000). We and others have demonstrated central neuropathic pain behaviors after SCI that correlate with the presence of dorsal horn hyperexcitability (Christensen and Hulsebosch, 1997; Hains, 2003a, b, 2003; Drew et al., 2001). Thus, SCI can also lead to central sensitization by mechanisms similar to peripheral nerve injury (Yezierski, 2000, Hulsebosch, 2003). For example, after SCI, there is a 37 fold increase in extracellular glutamate (Liu and McAdoo, 1993a). The increased concentrations of glutamate in the spinal cord activate glutamate receptor mediated biochemical pathways in dorsal horn neurons resulting in central sensitization. Similar events follow peripheral nerve injury, C fiber stimulation, or capsaicin injection (Yezierski, 2000, Hulsebosch, 2003). However, the central sensitization after SCI in the rodent contusion model persists for life (Hulsebosch et al., 2000; Hulsebosch, 2005), unlike that seen in peripheral injury models in whichpain persists for weeks at most. On the basis of these findings, it is important to determine at a cellular level the temporal changes in properties of dorsal horn neurons in different regions of the spinal cord following spinal cord contusion and the intracellular signaling involved.

A series of experiments focused on characterized cells in the dorsal horn that demonstrate hyperexcitability after SCI. Dorsal horn neurons were examined that respond to a range of both noxious and non-noxious stimuli, wide dynamic range (WDR) neurons, low threshold (best response to low threshold stimulus, LT) and high threshold (best response to high threshold stimulus, HT) neurons. In neuropathic pain models, dorsal horn neurons are characterized by their responses to somatic stimuli. In addition, the background activity is determined, and the receptive field is mapped. In general, when there is central sensitization, WDR cells have increased background activity, expanded receptive fields, increased after discharge rates, and increased responses to normally nonpainful mechanical stimuli (Christensen and Hulsebosch, 1997; Hains, et al., 2003a,b). The mechanisms that have been proposed to lead to central sensitization are listed above. Ways to prevent central sensitization as a result of SCI have not been fully explored. One goal of this study is to investigate the contributions of peripheral sensitization to altered sensory experience after SCI, particularly on above the spinal lesion level. In this region, release from descending inhibition, alterations due to injured peripheral components (ex. dorsal root injury) or injury to collateral central projections can not account for the altered conduction properties reported in the nerves of the forelimb.

\section{Peripheral Sensitization After SCI}

Following thoracic SCI, our preliminary data demonstrate peripheral sensitization of nociceptors in the glabrous skin of the forelimb (above level) but not in the hindlimb (below level). Peripheral sensitization is characterized by a lowering of the threshold to mechanical and heat stimuli and/or an increase in response to these stimuli (Carlton et al. 2001a, b; Du et al. 2001,2003). Although the process is not completely understood, sensitization can occur following activation of membrane receptors which are coupled to intracellular signal 
transduction cascades (Guenther et al 1999). Protein kinases in these cascades then phosphorylate molecules in the cytoplasm or ion channels and receptors in the membrane. The result is a lowered threshold to activation and/or an increased response to stimulation, known as peripheral sensitization (Lopshire and Nicol, 1998). Whereas it is commonly held that peripheral changes lead to central sensitization, paradoxically, changes in the chemical milieu in the spinal cord can lead to sensitization of primary sensory neurons in a retrograde fashion. For example, intrathecal injection of glutamate, NMDA, or prostaglandin $\mathrm{E}_{2}\left(\mathrm{PGE}_{2}\right)$ can cause mechanical hyperalgesia which can be attenuated by intraplantar injection of either morphine or the NO donor S-nitroso-N-acetyl-D,L-penicillamine (SNAP) (Ferreira and Lorenzetti, 1994, 1996). The authors hypothesize that once central terminals of primary afferents are sensitized, the change in membrane properties are rapidly extended by some unknown mechanism, resulting in "retrograde sensitization" of peripheral terminals of primary afferent. Reactive oxygen species (ROS) are formed by glutamate receptor over-activation and inflammatory pathways. It is possible that the 'retrograde sensitization' observed by Ferreira and Lorenzetti resulted from the generation of ROS following glutamate and $\mathrm{PGE}_{2}$ receptor activation. It is well known that SCI generates ROS; thus we hypothesize that ROS contribute to the peripheral sensitization observed following SCI. Of importance to the present consideration of SCI chronic pain, is the role of peripheral sensitization in central neuropathic pain syndromes. While peripheral sensitization has long been suspected to play a role in CNP, we provide the first demonstration of increased responsiveness of peripheral afferents to controlled stimuli after SCI, i.e., peripheral sensitization.

\section{Role of Reactive Oxygen Species in Central Sensitization in Regional Neuropathic Pain Following SCI Reactive Oxygen Species (ROS) in SCl}

Immediately after central nervous system injury, extracellular glutamate increases, glutamate receptor mediated intracellular pathways are activated (including increases in intracellular $\mathrm{Ca}^{2+}, \mathrm{COX}-2$ mediated prostaglandin pathways and the formation ROS, includinghydroxyl radicals, superoxide and nitric oxide (Kontos and Wei, 1986; Hall, 2003; Liu et al., 2004)) all of which lead to neuronal and glial death. The resultant oxidative stress promotes neutrophilmediated inflammation, that further exacerbates secondary damage (Juurlink and Paterson, 1998). Treatments with various superoxide dismutases, enzymes that convert superoxide to hydrogen peroxide, have lowered mortality in rodent models of SCI (Taoka, et al., 1995) and in ischemia or traumatic brain injury in humans (Muizelaar et al., 1993). A novel hypothesis is that ROS contributes to sensitization of dorsal horn neurons (central sensitization) through mechanisms that are currently unknown (see Chung, 2004), but may involve second messenger systems (Kim et al., 2004) and/or glial activation (Raghavendra et al., 2003). We propose that early and chronic removal of ROS after SCI will reduce intracellular signaling pathways that contribute to persistent glutamate receptor activation.

Early sources of ROS after SCI could be contributed by leukocytes (neutrophil, eosinophils, basophils, lymphocytes and monocytes) that are peripherally circulating cellular constituents that invade the spinal parenchyma after SCI (McTigue et al, 2000; Gris et al., 2004) and are thought to contribute to secondary damage through production of ROS (Carlson, et al., 1998). Thus, early treatment with ROS scavengers will provide protection from secondary damage and protect against ROS produced by a variety of cells, both infiltrating and SCI activated astrocytes and microglia (Nesic, et al., 2005). Chronic sources of ROS after SCI are most likely contributed by activated microglia and astrocytes. 


\section{Gliopathy Contributes to Chronic Pain}

Astrocytes are classically thought to play roles in potassium, glutamate and other transmitter regulation and homeostasis in extracellular and synaptic spaces via uptake mechanisms. Specialized astrocytes also play roles in the blood brain barrier and in neuronal nutritive functions (e.g. satellite cells of dorsal root ganglion neurons). Microglia are classically thought to be principally phagocytes that are mobilized after injury, infection, disease and seizures. When activated, glia cells are known to hypertrophy, increase production of cell specific "markers" (GFAP for astrocytes and OX-42 for microglia and other macrophages) and produce proinflammatory cytokines, ROS, ATP, excitatory amino acids, and nitric oxide (NO) (Johnstone et al., 1999; Martin, 1992; Piani et al., 1992; Shafer and Murphy, 1997; Tanaka et al., 1994); all of which are candidates for mediating pain following neural injury and are known to produce neuronal hyperexcitability in dorsal horn neurons, a necessary substrate for neuropathic pain (Figure 3).

It is interesting to note that the mechanisms of the differential regional pain all appear to have early and permanent activation of both microglia and astrocytes in common (for below-level: Hains and Waxman, 2006, Gwak et al., 2008; for at level-Crown et al., 2008; for above levelNesic et al., 2005). Perhaps the best of these studies is by Gwak et al., 2008. This study reports that following midthoracic SCI, the applicationof the phosphosodiesterase inhibitor propentofylline (PPF), that modulates both microglial and astrocytic activation (Tawfik, et al., 2007), results in decreased changes in the lumbar cord that include decreased mechanical allodynia, decreased GFAP and OX-42 expression, and decreased glial (both astrocytic and microglia) soma hypertrophy (also a classical marker for activation), as well as decreased neuronal hyperexcitability (Gwak et al., 2008). Thus, the conclusion is that inhibition of glia activation, both astrocytic and microglia, will improve chronic and persistent pain syndromes in remote segments below the level of lesion after SCI and in other central neuropathies. However, it is recognized that the mechanisms of astrocytic and microglial contributions to CNP are likely to be different between the two cell types and are likely to be different regionally in the same cell type (McKay et al., 2007).

In more recent work examining p38 activation, in astrocytes, microglia and dorsal horn neurons just rostral to the level of SCI, Crown et al., 2008 report that inhibiting the enzymatic activity of p38 MAPK reverses mechanical allodynia and decreases hyperexcitability in dorsal horn neurons. In addition, there is a SCI induced increase in GFAP and OX-42 protein expression that is attenuated by blocking activation of p38 MAPK. Thus, the conclusion is that glia activation, both astrocytic and microglia, have important roles in development and maintenance of persistent pain syndromes after SCI and other central neuropathies in regional neuropathic pain syndromes. Moreover, blocking specific intracellular signaling pathways can functionally alter the glia activation response and attenuate neuropathic pain syndromes (Hains and Waxman, 2006, Gwak et al., 2008; for at level-Crown et al., 2008; for above level-Nesic et al., 2005). In the mammalian system, we propose that normal glial function becomes abnormal and dysfunctional after CNS injury. The dysfunctional glial state contributes to conditions that initiate and ensure persistence of neuropathic pain. Whereas the concept of glia-neuronal and neuronal-glial interactions were described in invertebrate systems several decades ago (see Lasek et al., 1974; Villegas, 1972), the conceptual basis of dysfunctional glial cells contributing to neuropathic pain is relatively new (Crown et al., 2008; Detloff, et al., 2008; DeLeo et al., 2006; Gwak et al., 2008; Nesic et al., 2005; Romero-Sandoval, et al., 2008; Milligan et al., 2008).

We propose the term "gliopathy" to describe the dysfunctional and maladaptive response of glial cells to neural injury. We hypothesize that the initiation of gliopathy is the sudden increase in the extracellular concentration of glutamate after peripheral nerve injury (Rooney et al., 2007) and after SCI (McAdoo, et al., 1999) that in some cases is 37 fold higher than resting 
concentrations. This results in excitotoxicity (Xu et al., 2008) and glutamate receptor mediated sensitization of both neuronal and glial populations (Hulsebosch, 2005). With respect to the role of glutamate receptors in the dorsal horn excitability, we have published data that all glutamate receptor types (AMPA, kainate, metabotropic and NMDA) are involved in CNP. We know that NMDA receptor activation participates in the upregulation of several proinflammatory molecules (Nesic et al., 2002) and that proinflammatory cytokines exacerbate glutamate-mediated excitotoxicity after SCI (Hermann, et al., 2001). We hypothesize that one of the cellular sources for cytokine production after SCI is from the dysfunctional glial cells. (Of course, infiltrating cells are key contributors of proinflammatory cytokines and other sensitizing agents in early (Fleming et al., 2006) and late SCI (Nesic et al., 2005)). Furthermore, we hypothesize that persistent gliopathy occurs in regions near, as well as, remote from the spinal lesion (including the brain). The dysfunctional glial cells may continue to secrete proinflammatory cytokines and other sensitizing agents in both an autocrine and paracrine manner, creating persistent glial inflammation and continual sensitization of dorsal horn neurons (Hulsebosch, 2008).

\section{Concluding Summary}

In summary, it is obvious that the initial glutamate and proinflammatory cytokine increases that occur over the first few hours after SCI are not going to be useful therapeutic targets since most patients present to the emergency rooms 3 hours or later after injury. Additionally, differential regional mechanisms will contribute to the regional chronic pain states. However, we propose the importance of understanding the mechanisms in the differential regional pain syndromes after SCI in the chronic condition. Targeting regional mechanisms will be of enormous benefit to the SCI population that suffer chronic pain, and most likely will contribute to better treatment strategies for other chronic pain syndromes.

\section{Acknowledgments}

The authors would like to thank Ms. Debbie Pavlu for her superb administrative skills and support. This work was supported by the following grants: Mission Connect of TIRR Foundation, the Dunn Foundation, the West Foundation, Mr. Frank Liddell and NIH grants NS11255 and NS39161 to CEH; The American Pain Society and The Dana Foundation to BCH; The Christopher and Dana Reeve Paralysis Foundation CB1-0404-2 and Mission Connect of TIRR Foundation to EDC; and NS 54765 and NS 27910 to SMC.

\section{References}

Balazy TE. Clinical management of chronic pain in spinal cord injury. Clin J Pain 1992;8:102-110. [PubMed: 1633373]

Basbaum AI, Wall PD. Chronic changes in the response of cells in adult cat dorsal horn following partial deafferentation: the appearance of responding cells in a previously non-responding region. Brain Res 1976;116:181-204. [PubMed: 974771]

Bennett AD, Everhart AW, Hulsebosch CE. Intrathecal NMDA and non-NMDA receptor antagonists reduce mechanical but not thermal allodynia in a rodent model of chronic central pain after spinal cord injury. Brain Res 2000;859:72-82. [PubMed: 10720616]

Bruce JC, Oatway MA, Weaver LC. Chronic pain after clip-compression injury of the rat spinal cord. Exp Neurol 2002;178:33-48. [PubMed: 12460606]

Bunge, RP.; Puckett, WR.; Becerra, JL.; Marcillo, A.; Quencer, RM. Observations on the pathology of human spinal cord injury A review and classification of 22 new cases with details from a case of chronic cord compression with extensive focal demyelination. In: Seil, FJ., editor. Advances in Neurology. Vol. 59. Raven Press; New York: 1993. p. 75-89.

Bunge, RP. Clinical implications of recent advances in neurotrauma research. In: Salzman, SK.; Faden, AI., editors. The Neurobiology of Central Nervous System Trauma. Oxford Univ. Press; New York: 1994. p. 328-339. 
Cairns DM, Adkins RH, Scott MD. Pain and depression in acute traumatic spinal cord injury: Origins of chronic problematic pain? Arch Phys Med Rehab 1996;77:329-335.

Carbonell WS, Murase SI, Horwitz AF, Mandell JW. Infiltrative microgliosis: activation and longdistance migration of subependymal microglia following periventricular insults. J Neuroinflammation 2005;2:5. [PubMed: 15679892]

Carlson SL, Parrish ME, Springer JE, Doty K, Dossett L. Acute inflammatory response in spinal cord following impact injury. Exp Neurol 1998;151:77-88. [PubMed: 9582256]

Carlton SM, Du J, Davidson E, Zhou S, Coggeshall RE. Somatostatin receptors on peripheral primary afferent terminals: Inhibition of sensitized nociceptors. Pain 2001a;90:233-244. [PubMed: 11207395]

Carlton SM, Du J, Zhou S, Coggeshall RE. Tonic control of peripheral cutaneous nociceptors by somatostatin receptors. J Neurosci 2001b;21:4042-4049. [PubMed: 11356891]

Chang HT. Subacute human spinal cord contusion: few lymphocytes and many macrophages. Spinal Cord 2006;45:174-182. [PubMed: 16505827]

Christensen MD, Everhart AW, Pickelman JT, Hulsebosch CE. Mechanical and thermal allodynia in chronic central pain following spinal cord injury. Pain 1996;68:97-107. [PubMed: 9252004]

Christensen MD, Hulsebosch CE. Chronic central pain after spinal cord injury. J Neurotrauma 1997;14:517-537. [PubMed: 9300563]

Chung JM. The role of reactive oxygen species (ROS) in persistent pain. Mol Interventions 2004;4:248250.

Columba-Cabezas S, Serafini B, Ambrosini E, Aloisi F. Lymphoid chemokines CCL19 and CCL21 are expressed in the central nervous system during experimental autoimmune encephalomyelitis: implications for the maintenance of chronic neuroinflammation. Brain Pathol 2003;13:38-51. [PubMed: 12580544]

Coyle DE. Partial peripheral nerve injury leads to activation of astroglia and microglia which parallels the development of allodynic behavior. Glia 1998;23:75-83. [PubMed: 9562186]

Crown ED, Ye Z, Johnson KM, Xu GY, McAdoo DJ, Westlund KN, Hulsebosch CE. Upregulation of the phosphorylated form of CREB in spinothalamic tract cells following spinal cord injury: relation to central neuropathic pain. Neurosci Lett 2005;384:139-144. [PubMed: 15896906]

Crown ED, Ye Z, Johnson KM, Xu GY, McAdoo DJ, Hulsebosch CE. Increases in the activated forms of ERK 1/2, p38 MAPK, and CREB are correlated with the expression of at-level mechanical allodynia following spinal cord injury. Exp Neurol 2006;199:397-407. [PubMed: 16478624]

Crown ED, Gwak YS, Ye Z, Johnson KM, Hulsebosch CE. Activation of p38 MAP kinase is involved in central neuropathic pain following spinal cord injury. Exp Neurol 2008;213:257-267. [PubMed: 18590729]

Davidoff, G.; Roth, EJ. Clinical characteristics of central (Dysesthetic) pain in spinal cord injury patients. In: Casey, KL., editor. Pain and Central Nervous System Disease: The Central Pain Syndromes. Raven Press; New York: 1991. p. 77-83.

de Jong EK, Dijkstra IM, Hensens M, Brouwer N, van Amerongen M, Liem RS, Boddeke HW, Biber K. Vesicle-mediated transport and release of CCL21 in endangered neurons: a possible explanation for microglia activation remote from a primary lesion. J Neurosci 2005;25:7548-7557. [PubMed: 16107642]

DeLeo JA, Tawfik VL, LaCroix-Fralish ML. The tetrapartite synapse: path to CNS sensitization and chronic pain. Pain 2006;122:17-21. [PubMed: 16564626]

Detloff MR, Fisher LC, McGaughy V, Longbrake EE, Popovich PG, Basso DM. Remote activation of microglia and pro-inflammatory cytokines predict the onset and severity of below-level neuropathic pain after spinal cord injury in rats. Exp Neurol 2008;212:337-347. [PubMed: 18511041]

Devor M, Wall PD. Plasticity in the spinal cord sensory map following peripheral nerve injury in rats. $\mathbf{J}$ Neurosci 1981;1:679-684. [PubMed: 7346576]

Dijkstra M, Hulshof S, van der Valk P, Boddeke HWGM, Biber K. Functional activity of human adult microglia in response to CCL21. J Immunol 2004;172:2744-2747. [PubMed: 14978072]

Dijkstra IM, de Haas AH, Brouwer N, Boddeke HW, Biber K. Challenge with innate and protein antigens induces CCR7 expression by microglia in vitro and in vivo. Glia 2006;54:861-872. [PubMed: 16977602] 
Drew GM, Siddall PJ, Duggan AW. Responses of spinal neurones to cutaneous and dorsal root stimuli in rats with mechanical allodynia after contusive spinal cord injury. Brain Res 2001;893:59-69. [PubMed: 11222993]

Du J, Koltzenburg M, Carlton SM. Glutamate-induced excitation and sensitization of nociceptors in rat glabrous skin. Pain 2001;89:187-198. [PubMed: 11166475]

Du J, Zhou S, Coggeshall RE, Carlton SM. N-methyl-D-aspartate-induced excitation and sensitization of normal and inflamed nociceptors. Neuroscience 2003;118:547-562. [PubMed: 12699789]

Faden AI, Simon RP. A potential role for excitotoxins in the pathophysiology of spinal cord injury. Ann Neurol 1988;23:623-626. [PubMed: 2841902]

Ferreira SH, Lorenzetti BB. Glutamate spinal retrograde sensitization of primary sensory neurons associated with nociception. Neuropharmacology 1994;33:1479-1485. [PubMed: 7532832]

Ferreira SH, Lorenzetti BB. Intrathecal administration of prostaglandin E2 causes sensitization of the primary afferent neuron via the spinal release of glutamate. Inflamm Res 1996;45:499-502. [PubMed: 8912014]

Finnerup NB, Johannesen IL, Sindrup SH, Bach FW, Jensen TS. Pain and dysesthesia in patients with spinal cord injury: A postal survey. Spinal Cord 2001;39:256-262. [PubMed: 11438841]

Fleming JC, Norenberg MD, Ramsay DA, Dekaban GA, Marcillo AE, Saenz AD, Pasquale-Styles M, Dietrich WD, Weaver LC. The cellular inflammatory response in human spinal cords after injury. Brain 2006;129:3249-3269. [PubMed: 17071951]

Fu KY, Light AR, Matsushima GK, Maixner W. Microglial reactions after subcutaneous formalin injection into the rat hind paw. Brain Res 1999;825:59-67. [PubMed: 10216173]

Ginty DD, Bonni A, Greenberg ME. Nerve growth factor activates a Ras-dependent protein kinase that stimulates c-fos transcription via phosphorylation of CREB. Cell 1994;77:713-725. [PubMed: 8205620]

Gris D, Marsh DR, Oatway MA, Chen Y, Hamilton EF, Dekaban GA, Weaver LC. Transient blockade of the CD11d/CD18 integrin reduces secondary damage after spinal cord injury, improving sensory, autonomic, and motor function. J Neurosci 2004;24:4043-4051. [PubMed: 15102919]

Guenther S, Reeh PW, Kress M. Rises in $\left[\mathrm{Ca}_{2}{ }^{+}\right]_{1}$ mediate capsaicin- and proton-induced heat sensitization of rat primary nociceptive neurons. Eur J Neurosci 1999;11:3143-3150. [PubMed: 10510178]

Gunn MD, Kyuwa S, Tam C, Kakiuchi T, Matsuzawa A, Williams LT, Nakano H. Mice lacking expression of secondary lymphoid organ chemokine have defects in lymphocyte homing and dendritic cell localization. J Exp Med 1999;189:451-460. [PubMed: 9927507]

Gwak YS, Crown ED, Unabia GC, Hulsebosch CE. Protentyfylline attenuates allodynia, glial activation and modulates GABAergic tone after spinal cord injury in the rat. Pain 2008;138:410-422. [PubMed: 18353556]

Hains BC, Everhart AW, Fullwood SD, Hulsebosch CE. Changes in serotonin, serotonin transporter expression and serotonin denervation supersensitivity: Involvement in chronic central pain after spinal hemisection in the rat. Exp Neurol 2002;175:347-362. [PubMed: 12061865]

Hains BC, Johnson KM, Eaton MJ, Willis WD, Hulsebosch CE. Serotonergic neural precursor cell grafts attenuate bilateral hyperexcitability of dorsal horn neurons after spinal hemisection in rat. Neuroscience 2003a;116:1097-1110. [PubMed: 12617951]

Hains BC, Willis WD, Hulsebosch CE. Serotonin receptors 5-HT1A and 5-HT3 reduce hyperexcitability of dorsal horn neurons after chronic spinal cord hemisection injury in rat. Exp Brain Res 2003b; 149:174-186. [PubMed: 12610685]

Hains BC, Klein JP, Saab CY, Craner MJ, Black JA, Waxman SG. Upregulation of sodium channel Nav1.3 and functional involvement in neuronal hyperexcitability associated with central neuropathic pain after spinal cord injury. J Neurosci 2003c;23:8881-8892. [PubMed: 14523090]

Hains BC, Waxman SG. Activated microglia contribute to the maintenance of chronic pain after spinal cord injury. J Neurosci 2006;26:4308-4317. [PubMed: 16624951]

Hall ED. Drug development in spinal cord injury: What is the FDA looking for? J Rehab Devel 2003;40:81-92.

Hanisch UK, Kettenmann H. Microglia: active sensor and versatile effector cells in the normal and pathologic brain. Nat Neurosci 2007;10:1387-1394. [PubMed: 17965659] 
Hao JX, Xu XJ, Aldskogious H, Seiger A, Wiesenfeld-Hallin Z. Allodynia-like effects in the rat after ischemic spinal cord injury photochemically induced by laser irradiation. Pain 1991;45:175-185. [PubMed: 1652116]

Hao JX, Watson BD, Xu XJ, Wiesenfeld-Hallin Z, Seiger A, Sundström E. Protective effect of the NMDA antagonist MK-801 on photochemically induced spinal lesions in the rat. Exp Neurol 1992;118:14352. [PubMed: 1426124]

Hermann GE, Rogers RC, Bresnahan JC, Beattie MS. Tumor-necrosis factor-alpha induces cFOS and strongly potentiates glutamate-mediated cell death in the rat spinal cord. Neurobiol Dis 2001;8:590599. [PubMed: 11493024]

Hulsebosch CE, Xu GY, Perez-Polo JR, Westlund KN, Taylor CP, McAdoo DJ. Rodent model of chronic central pain after spinal cord contusion injury and effects of gabapentin. J Neurotruama 2000;17:1205-1217.

Hulsebosch CE. Mechanisms and treatment strategies for chronic central neuropathic pain after spinal cord injury. Top Spinal Cord Inj Rehabil 2003;8:76-91.

Hulsebosch CE. From discovery to clinical trials: treatment strategies for central neuropathic pain after spinal cord injury. Curr Pharm Des 2005;11:1411-1420. [PubMed: 15853671]

Hulsebosch CE. Gliopathy ensures persistent inflammation and chronic pain after spinal cord injury. Exp Neurol. 2008

Impey S, Obrietan K, Storm DR. Making new connections: Role of ERK/MAP kinase signaling in neuronal plasticity. Neuron 1999;23:11-14. [PubMed: 10402188]

Ji RR, Woolf CJ. Neuronal plasticity and signal transduction in nociceptive neurons: implications for the initiation and maintenance of pathological pain. Neurobiol Dis 2001;8:1-10. [PubMed: 11162235]

Ji RR, Befort K, Brenner GJ, Woolf CJ. ERK MAP kinase activation in superficial spinal cord neurons induces prodnorphin and NK-1 upregulation and contributes to persistent inflammatory pain hypersensitivity. J Neurosci 2002;22:478-485. [PubMed: 11784793]

Ji RR, Kohno T, Moore KA, Woolf CJ. Central sensitization and LTP: do pain and memory share similar mechanisms? Trends Neurosci 2003;26:696-705. [PubMed: 14624855]

Ji RR. Peripheral and central mechanisms of inflammatory pain, with emphasis on MAP kinases. Curr Drug Targets Inflamm Allergy 2004;3:299-303. [PubMed: 15379598]

Ji RR, Strichartz G. Cell signaling and the genesis of neuropathic pain. Science STKE 2004;252:re14.

Ji RR, Suter MR. p38 MAPK, microglial signaling, and neuropathic pain. Mol Pain 2007;3:33. [PubMed: 17974036]

Jin SX, Zhuang ZY, Woolf CJ, Ji RR. p38 mitogen-activated protein kinase is activated after a spinal nerve ligation in spinal cord microglia and dorsal root ganglion neurons and contributes to the generation of neuropathic pain. J Neurosci 2003;23:4017-4022. [PubMed: 12764087]

Johnstone M, Gearing AJ, Miller KM. A central role for astrocytes in the inflammatory response to betaamyloid; chemokines, cytokines and reactive oxygen species are produced. J Neuroimmunol 1999;93:182-193. [PubMed: 10378882]

Juurlink BH, Paterson PG. Review of oxidative stress in brain and spinal cord injury: suggestions for pharmacological and nutritional management strategies. J Spinal Cord Med 1998;21:309-334. [PubMed: 10096045]

Kim HK, Park SK, Zhou JL, Taglialatela G, Chung K, Coggeshall RE, Chung JM. Reactive oxygen species (ROS) play an important role in a rat model of neuropathic pain. Pain 2004;111:116-124. [PubMed: 15327815]

Kontos HA, Wei EP. Superoxide production in experimental brain injury. J Neurosurg 1986;64:803-807. [PubMed: 3009736]

Kurpius D, Wilson N, Fuller L, Hoffman A, Dailey ME. Early activation, motility, an d homing of neonatal microglia to injured neurons does not require protein synthesis. Glia 2006;54:58-70. [PubMed: 16715500]

Lampert A, Hains BC, Waxman SG. Upregulation of persistent and ramp sodium current in dorsal horn neurons after spinal cord injury. Exp Brain Res 2006;174:660-666. [PubMed: 16718433]

Lasek RJ, Gainer H, Przybylski RJ. Transfer of newly synthesized proteins from Schwann cells to the squid giant axon. Proc Natl Acad Sci USA 1974;71:1188-1192. [PubMed: 4524631] 
Ledeboer A, Sloane EM, Milligan ED, Frank MG, Mahony JH, Maier SF, Watkins LR. Minocycline attenuates mechanical allodynia and proinflammatory cytokine expression in rat models of pain facilitation. Pain 2005;115:71-83. [PubMed: 15836971]

Lenz FA, Kwan HC, Martin R, Tasker R, Richardson RT, Dostrovsky JO. Characteristics of somatotopic organization and spontaneous neuronal activity in the region of the thalamic principal sensory nucleus in patients with spinal cord transaction. J Neurophysiol 1994;72:1570-1587. [PubMed: 7823087]

Lindsey AE, LoVerso RI, Tovar CA, Hill CE, Beattie MS, Bresnahan JC. An analysis of changes in sensory thresholds to mild tactile and cold stimuli after experimental spinal cord injury in the rat. Neurorehab Neural Repair 2000;14:287-300.

Liu D, Thangnipon W, McAdoo DJ. Excitatory amino acids rise to toxic levels upon impact injury to the rat spinal cord. Brain Res 1991;547:344-348. [PubMed: 1884213]

Liu D, McAdoo DJ. Methylprednisolone reduces excitatory amino acid release following experimental spinal cord injury. Brain Res 1993;609:293-297. [PubMed: 8508311]

Liu D, Xu GY, Pan E, McAdoo DJ. Neurotoxicity of glutamate at the concentration released upon spinal cord injury. Neuroscience 1999;93:1383-1389. [PubMed: 10501463]

Liu D, Liu J, Sun D, Wen J. The time course of hydroxyl radical formation following spinal cord injury: the possible role of the iron-catalyzed Haber-Weiss reaction. J Neurotrauma 2004;21:805-816. [PubMed: 15253806]

Loeser JD, Ward AA Jr, White LE. Chronic deafferentation of human spinal cord neurons. J Neurosurg 1968;29:48-50. [PubMed: 5244625]

Lombard MC, Nashold BS, Albe-Fessard D. Deafferentation hypersensitivity in the rat after dorsal rhizotomy: possible animal model for chronic pain. Pain 1979;6:163-174. [PubMed: 460928]

Lonz BE, Ginty DD. Function and regulation of CREB family transcription factors in the nervous system. Neuron 2002;35:605-623. [PubMed: 12194863]

Lopshire JC, Nicol GD. The cAMP transduction cascade mediates the prostaglandin E2 enhancement of the capsaicin-elicited current in rat sensory neurons: whole-cell and single-channel studies. $\mathbf{J}$ Neurosci 1998;18:6081-6-92. [PubMed: 9698303]

Marchand F, Perretti M, McMahon SB. Role of the immune system in chronic pain. Nat Rev Neurosci 2005;6:521-532. [PubMed: 15995723]

Martin DD. Synthesis and release of neuroactive substances by glia cells. Glia 1992;5:81-94. [PubMed: 1349588]

McAdoo DJ, Xu GY, Robak G, Hughes MG. Changes in amino acid concentrations over time and space around an impact injury and their diffusion through the rat spinal cord. Exp Neurol 1999;159:538544. [PubMed: 10506525]

McKay SM, Brooks DJ, Hu P, McLachlan EM. Distinct types of microglial activation in white and grey matter of rat lumbosacral cord after mid-thoracic spinal transection. J Neuropathol Exp Neurol 2007;66:698-710. [PubMed: 17882014]

McTigue DM, Popovich PG, Jakeman LB, Stokes BT. Strategies for spinal cord repair. Prog Brain Res 2000;128:3-8. [PubMed: 11105664]

Milligan ED, Zapata V, Chacur M, Schoeniger D, Biedenkapp J, O'Connor KA, Verge GM, Chapman G, Green P, Foster AC, Naeve GS, Maier SF, Watkins LR. Evidence that exogenous and endogenous fractalkine can induce spinal nociceptive facilitation in rats. Eur J Neurosci 2004;20:2294-2302. [PubMed: 15525271]

Milligan ED, Sloane EM, Watkins LR. Glia in pathological pain: A role for fractalkine. J Neuroimmunol 2008;198:113-120. [PubMed: 18547654]

Mills CD, Grady JJ, Hulsebosch CE. Changes in exploratory behavior as a measure of chronic central pain following spinal cord injury. J Neurotrauma 2001a;18:1091-1105. [PubMed: 11686495]

Mills CD, Hulsebosch CE. Increased expression of metabotropic glutamate receptor subtype 1 on spinothalamic tract neurons following spinal cord injury in the rat. Neurosci Lett 2002a;319:59-62. [PubMed: 11825670]

Mills CD, Johnson KM, Hulsebosch CE. Group I metabotropic glutamate receptors in spinal cord injury: Roles in neuroprotection and the development of chronic central pain. J Neurotrauma 2002;19:2342. [PubMed: 11852976] 
Moalem G, Tracey DJ. Immune and inflammatory mechanisms in neuropathic pain. Brain Res Rev 2006;51:240-264. [PubMed: 16388853]

Muizelaar JP, Marmarou A, Young HF, Choi SC, Wolf A, Schneider RL, Kontos HA. Improving the outcome of severe head injury with the oxygen radical scavenger polyethylene glycol-conjugated superoxide dismutase: a phase II trial. J Neurosurg 1993;78:375-383. [PubMed: 8433137]

Murphy PM, Baggiolini M, Charo IF, Hebert CA, Horuk R, Matsushima K, Miller LH, Oppenheim JJ, Power CA. International union of pharmacology. XXII. Nomenclature for chemokine receptors. Pharmacol Rev 2000;52:145-176. [PubMed: 10699158]

Nakata Y, Kusaka Y, Segawa T. Supersensitivity to substance P after dorsal root section. Life Sci 1979;24:1651-1654. [PubMed: 481100]

Nesic O, Svrakic NM, Xu GY, McAdoo D, Westlund KN, Hulsebosch CE, Ye Z, Galante A, Soteropoulos P, Tolias P, Young W, Hart RP, Perez-Polo JR. DNA microarray analysis of the contused spinal cord: Effect of NMDA receptor inhibition. J Neurosci Res 2002;68:406-423. [PubMed: 11992467]

Nesic O, Lee J, Johnson KM, Ye Z, Xu GY, Unabia GC, Wood TG, McAdoo DJ, Westlund KN, Hulsebosch CE, Perez-Polo JR. Transcriptional profiling of spinal cord injury-induced central neuropathic pain. J Neurochem 2005;95:998-1014. [PubMed: 16219025]

Neugebauer V, Lücke T, Schaible HG. Requirement of metabotropic glutamate receptors for the generation of inflammation-evoked hyperexcitability in rat spinal cord neurons. Eur J Neurosci 1994;6:1179-1186. [PubMed: 7524965]

Nguyen PV, Kandel ER. A macromolecular synthesis dependent late phase of long-term potentiation requiring cAMP in the medial perforant pathway of rat hippocampal slices. J Neurosci 1996;16:31893198. [PubMed: 8627357]

Ovelmen-Levitt J, Gorecki J, Nguyen K, Iskandar B, Nashold BS Jr. Spontaneous and evoked dysesthesias observed in the rat after spinal cordotomies. Stereotact Funct Neurosurg 1995;65:157160. [PubMed: 8916347]

Palecek J, Dougherty PM, Kim SH, Paleckova V, Lekan H, Chung JM, Carlton SM, Willis WD. Responses of spinothalamic tract neurons to mechanical and thermal stimuli in an experimental model of peripheral neuropathy in primates. J Neurophysiol 1992a;68:1951-1966. [PubMed: 1337100]

Palecek J, Paleckova V, Dougherty PM, Carlton SM, Willis WD. Responses of spinothalamic tract cells to mechanical and thermal stimulation of skin in rats with experimental peripheral neuropathy. $\mathrm{J}$ Neurophysiol 1992b;67:1562-1573. [PubMed: 1321241]

Piani D, Spranger M, Frei K, Schaffner A, Fontana A. Macrophage-induced cytotoxicity of N-methylD-aspartate receptor positive neurons involves excitatory amino acids rather than reactive intermediates and cytokines. Eur J Immunol 1992;22:2429-2439. [PubMed: 1355433]

Raghavendra V, Tanga F, DeLeo JA. Inhibition of microglial activation attenuates the development but not existing hypersensitivity in a rat model of neuropathy. J Pharmacol Exp Ther 2003;306:624630. [PubMed: 12734393]

Rappert A, Biber K, Nolte C, Lipp M, Schubelm A, Lu B, Gerard NP, Gerard C, Boddeke HW, Kettenmann H. Secondary lymphoid tissue chemokine (CCL21) activates CXCR3 to trigger a Clcurrent and chemotaxis in murine microglia. J Immunol 2002;168:3221-3226. [PubMed: 11907075]

Rappert A, Bechmann I, Pivneva T, Mahlo J, Biber K, Nolte C, Kovac AD, Gerard C, Boddeke HW, Nitsch R, Kettenmann H. CXCR3-dependent microglial recruitment is essential for dendrite loss after brain lesion. J Neurosci 2004;24:8500-8509. [PubMed: 15456824]

Ren K, Dubner R. Central nervous system plasticity and persistent pain. J Orofac Pain 1999;13:155-163. [PubMed: 10823030]

Richards JS, Meredith RL, Nepomuceno C, Fine PR, Bennett G. Psycho-social aspects of chronic pain in spinal cord injury. Pain 1980;8:355-366. [PubMed: 7402693]

Rinaldi PC, Young RF, Albe-Fessard D, Chodakiewitz J. Spontaneous hyperactivity in the medial and intralaminar thalamic nuclei of patients with deafferentation pain. J Neurosurg 1991;74:415-421. [PubMed: 1993906]

Rintala DH, Loubser PG, Castro J, Hart KA, Fuhrer MJ. Chronic pain in a community-based sample of men with spinal cord injury: prevalence, severity, and relationship with impairment, disability, 
handicap, and subjective well-being. Arch Phys Med Rehabil 1998;79:604-614. [PubMed: 9630137]

Roberson ED, English JD, Adams JP, Selcher JC, Kondratick C, Sweatt JD. The mitogen-activated protein kinase cascade couoples PKA and PKC to cAMP response element binding protein phosphorylation in area CA1 of hippocampus. J Neurosci 1999;19:4337-4348. [PubMed: 10341237]

Romero-Sandoval EA, Horvath RJ, DeLeo JA. Neuroimmune interactions and pain: Focus on glialmodulating targets. Curr Opin Investig Drugs 2008;9:726-734.

Rooney BA, Crown ED, Hulsebosch CE, McAdoo DJ. Preemptive analgesia with lidocaine prevents failed back surgery syndrome. Exp Neurol 2007;204:589-596. [PubMed: 17261281]

Schmitt AB, Buss A, Breuer S, Brook GA, Pech K, Martin D, Schoenen J, Noth J, Love S, Schröder JM, Kreutzberg GW, Nacimiento W. Major histocompatibility complex class II expression by activated microglia caudal to lesions of descending tracts in the human spinal cord is not associated with a T cell response. Acta Neuropathol 2000;100:528-536. [PubMed: 11045675]

Segatore M. Understanding chronic pain after spinal cord injury. J Neurosci Nursing 1994;26:230-2236.

Sekhon LH, Fehlings MG. Epidemiology, demographics, and pathophysiology of acute spinal cord injury. Spine 2001;26:S2-12. [PubMed: 11805601]

Serafini B, Rosicarelli B, Magliozzi R, Stigliano E, Capello E, Mancardi GL, Aloisi F. Dendritic cells in multiple sclerosis lesions: maturation stage, myelin uptake, and interaction with proliferating $\mathrm{T}$ cells. J Neuropathol Exp Neurol 2006;65:124-141. [PubMed: 16462204]

Shafer RA, Murphy S. Activated astrocytes induce nitric oxide synthase-2 in cerebral endothelium via tumor necrosis factor alpha. Glia 1997;21:370-379. [PubMed: 9419012]

Sheng M, Thompson MA, Greenberg ME. CREB: a $\left(\mathrm{Ca}\left(2^{+}\right)\right.$-regulated transcription factor phosphorylated by calmodulin-dependent kinases. Science 1991;252:1427-1430. [PubMed: 1646483]

Siddall P, Xu CL, Cousins M. Allodynia following traumatic spinal cord injury in the rat. NeuroReport 1995;6:1241-1244. [PubMed: 7669978]

Siddall, PJ.; Yezierski, RP.; Loeser, JD. Taxonomy and epidemiology of spinal cord injury pain In Sspinal Cord Injury Pain: Assessment, Mechanisms, Management Progress. In: Yezierski, RP.; Burchiel, KJ., editors. Pain Research and Management. Vol. 23. IASP Press; Seattle: 2002. p. 9-24.

Siddall PJ, McClelland JM, Rutkowski SB, Cousins MJ. A longitudinal study of the prevalence and characteristics of pain in the first 5 years following spinal cord injury. Pain 2003;103:249-257. [PubMed: 12791431]

Sjolund BH. Pain and rehabilitation after spinal cord injury: the case of sensory spasticity? Brain Res Res Rev 2002;40:250-256.

Sørensen JC, Dalmau I, Zimmer J, Finsen B. Microglial reactions to retrograde degeneration of traceridentified thalamic neurons after frontal sensorimotor cortex lesions in adult rats. Exp Brain Res 1996;112:203-212. [PubMed: 8951389]

Soto H, Wang W, Strieter RM, Copeland NG, Gilbert DJ, Jenkins NA, Hedrick J, Zlotnik A. The CC chemokine 6Ckine binds the CXC chemokine receptor CXCR3. Proc Natl Acad Sci 1998;95:82058210. [PubMed: 9653165]

Sroga JM, Jones TB, Kigerl KA, McGaughy VM, Popovich PG. Rats and mice exhibit distinct inflammatory reactions after spinal cord injury. J Comp Neurol 2003;462:223-240. [PubMed: 12794745]

Streit WJ, Walter SA, Pennell NA. Reactive microgliosis. Prog Neurobiol 1999;57:563-581. [PubMed: 10221782]

Sweatt JD. The neuronal MAP kinase cascade: a biochemical signal integration system subserving synaptic plasticity and memory. J Neurochem 2001;76:1-10. [PubMed: 11145972]

Tanaka M, Sotomatsu A, Yoshida T, Hirai S, Nishida A. Detection of superoxide production by activated microglia using a sensitive and specific chemiluminescence assay and microglia-mediated PC12h cell death. J Neurochem 1994;63:266-270. [PubMed: 8207432]

Taoka Y, Naruo M, Koyanagi E, Urakado M, Inoue M. Superoxide radicals play important roles in the pathogenesis of spinal cord injury. Paraplegia 1995;33:450-453. [PubMed: 7478738] 
Tasker, RR.; Dostrovsky, JO. Deafferentation and central pain. In: Wall, PD.; Melzack, R., editors. Textbook of Pain. Churchill Livingstone; New York: 1989. p. 154-180.

Tator CH, Fehlings MG. Review of the secondary injury theory of acute spinal cord trauma with emphasis on vascular mechanisms. J Neurosurg 1991;75:15-26. [PubMed: 2045903]

Tawfik VL, Nutile-McMenemy N, LaCroix-Fralish ML, DeLeo JA. Efficacy of propentofylline, a glial modulating agent, on existing mechanical allodynia following peripheral nerve injury. Brain Behav Immunity 2007;21:238-246.

Turner JA, Cardenas DD, Warms CA, McClellan CB. Chronic pain associated with spinal cord injuries: a community survey. Arch Phys Med Rehabil 2001;82:501-509. [PubMed: 11295011]

Vela JM, Yáñez A, González B, Castellano B. Time course of proliferation and elimination of microglia/ macrophages in different neurodegenerative conditions. J Neurotrauma 2002;19:1503-1520. [PubMed: 12490014]

Vera-Portocarrero LP, Mills CD, Ye Z, Fullwood SD, McAdoo DJ, Hulsebosch CE, Westlund KN. Rapid changes in expression of glutamate transporters after spinal cord injury. Brain Res 2002;927:104110. [PubMed: 11814437]

Verge GM, Milligan ED, Maier SF, Watkins LR, Naeve GS, Foster AC. Fractalkine (CX3CL1) and fractalkine receptor (CX3CR1) distribution in spinal cord and dorsal root ganglia under basal and neuropathic pain conditions. Eur J Neurosci 2004;20:1150-1160. [PubMed: 15341587]

Vierck, CJ., Jr; Light, AR. Allodynia and hyperalgesia within dermatomes caudal to a spinal cord injury in primates and rodents. In: Sandkuhler, J.; Bromm, B.; Gebhart, G., editors. Nervous System Plasticity and Chronic Pain. Vol. 129. Elsevier; Amsterdam: 2000. p. 411-428.

Vierck CJ Jr, Siddall P, Yezierski RP. Pain following spinal cord injury: animal models and mechanistic studies. Pain 2000;89:1-5. [PubMed: 11113287]

Villegas J. Axon-Schwann cell interaction in the squid nerve fibre. J Physiol 1972;225:275-296. [PubMed: 5074387]

Watkins LR, Milligan ED, Maier SF. Glial activation: a driving force for pathological pain. Trends in Neurosciences 2001;24:450-455. [PubMed: 11476884]

Watkins LR, Hutchinson MR, Ledeboer A, Wieseler-Frank J, Milligan ED, Maier SF. Glia as the "bad guys": implications for improving clinical pain control and the clinical utility of opioids. Brain Behav Immun 2007;21:131-146. [PubMed: 17175134]

Waxman SG. Acquired channelopathies in nerve injury and MS. Neurology 2001;56:1621-1627. [PubMed: 11428390]

White FA, Bhangoo SK, Miller RJ. Chemokines: integrators of pain and inflammation. Nat Rev Drug Discov 2005a;4:834-844. [PubMed: 16224455]

White FA, Sun J, Waters SM, Ma C, Ren D, Ripsch M, Steflik J, Cortright DN, Lamotte RH, Miller RJ. Excitatory monocyte chemoattractant protein-1 signaling is up-regulated in sensory neurons after chronic compression of the dorsal root ganglion. Proc Natl Acad Sci 2005b;102:14092-14097. [PubMed: 16174730]

Wieseler-Frank J, Maier SF, Watkins LR. Central proinflammatory cytokines and pain enhancement. Neurosignals 2005;14:166-174. [PubMed: 16215299]

Willis, WD, Jr. Central sensitization and plasticity following intense noxious stimulation. In: Moyer, EA.; Raybould, HE., editors. Basic and Clinical Aspects of Chronic Abdominal Pain. Elsevier Science Publ; 1993a. p. 201-217.

Willis WD Jr. Mechanical allodynia: A role for sensitized nociceptive tract cells with convergent input from mechanoreceptors and nociceptors? APS J 1993b;2:23-33.

Willis WD. Role of neurotransmitters in sensitization of pain responses. Ann NY Acad Sci 2001;933:142156. [PubMed: 12000017]

Woolf CJ. Evidence for a central component of post-injury pain hypersensitivity. Nature 1983;306:686688. [PubMed: 6656869]

Woolf CJ. The pathophysiology of peripheral neuropathic pain-abnormal peripheral input and abnormal central processing. Acta Neurochir Suppl 1993;58:125-130.

Wright DM, Roberts MH. Supersensitivity to substance P analogue following dorsal root section. Life Sci 1978;22:19-24. [PubMed: 625185] 
Xu GY, Liu S, Hughes MG, McAdoo DJ. Glutamate-induced losses of oligodendrocytes and neurons and activation of caspase-3 in the rat spinal cord. Neuroscience 2008;153:1034-1047. [PubMed: 18423997]

Xu XJ, Hao JX, Aldskogius H, Seiger A, Wiesenfeld-Hallin Z. Chronic pain-related syndrome in rats after ischemic spinal cord lesion: a possible animal model for pain in patients with spinal cord injury. Pain 1992;48:279-290. [PubMed: 1589248]

Yezierski RP, Park SH. The mechanosensitivity of spinal sensory neurons following intraspinal injections of quisqualic acid in the rat. Neurosci Lett 1993;157:115-119. [PubMed: 8233021]

Yezierski RP, Liu S, Ruenes GL, Kajander KJ, Brewer KL. Excitotoxic spinal cord injury - behavioral and morphological characteristics of a central pain model. Pain 1998;75:141-155. [PubMed: 9539683]

Yezierski RP. Pain following spinal cord injury: pathophysiology and central mechanisms. Prog Brain Res 2000;129:429-449. [PubMed: 11098709]

Zai LJ, Wrathall JR. Cell proliferation and replacement following contusive spinal cord injury. Glia 2005;50:247-257. [PubMed: 15739189]

Zhang J, De Koninck Y. Spatial and temporal relationship between monocyte chemoattractant protein-1 expression and spinal glial activation following peripheral nerve injury. J Neurochem 2006;97:772783. [PubMed: 16524371]

Zhao P, Waxman SG, Hains BC. Extracellular signal-regulated kinase-regulated microglia-neuron signaling by prostaglandin E2 contributes to pain after spinal cord injury. J Neurosci 2007a; 27:2357-2368. [PubMed: 17329433]

Zhao P, Waxman SG, Hains BC. Modulation of thalamic nociceptive processing after spinal cord injury through remote activation of thalamic microglia by cysteine cysteine chemokine ligand 21 . J Neurosci 2007b;27:8893-8902. [PubMed: 17699671]

Zhou X, Lin Q, Willis WD. Enhanced phosphorylation of NMDA receptor 1 subunits in spinal cord dorsal horn and spinothalamic tract neurons after intradermal injection of capsaicin in rats. J Neurosci 2000;20:6989-6997. [PubMed: 10995844] 


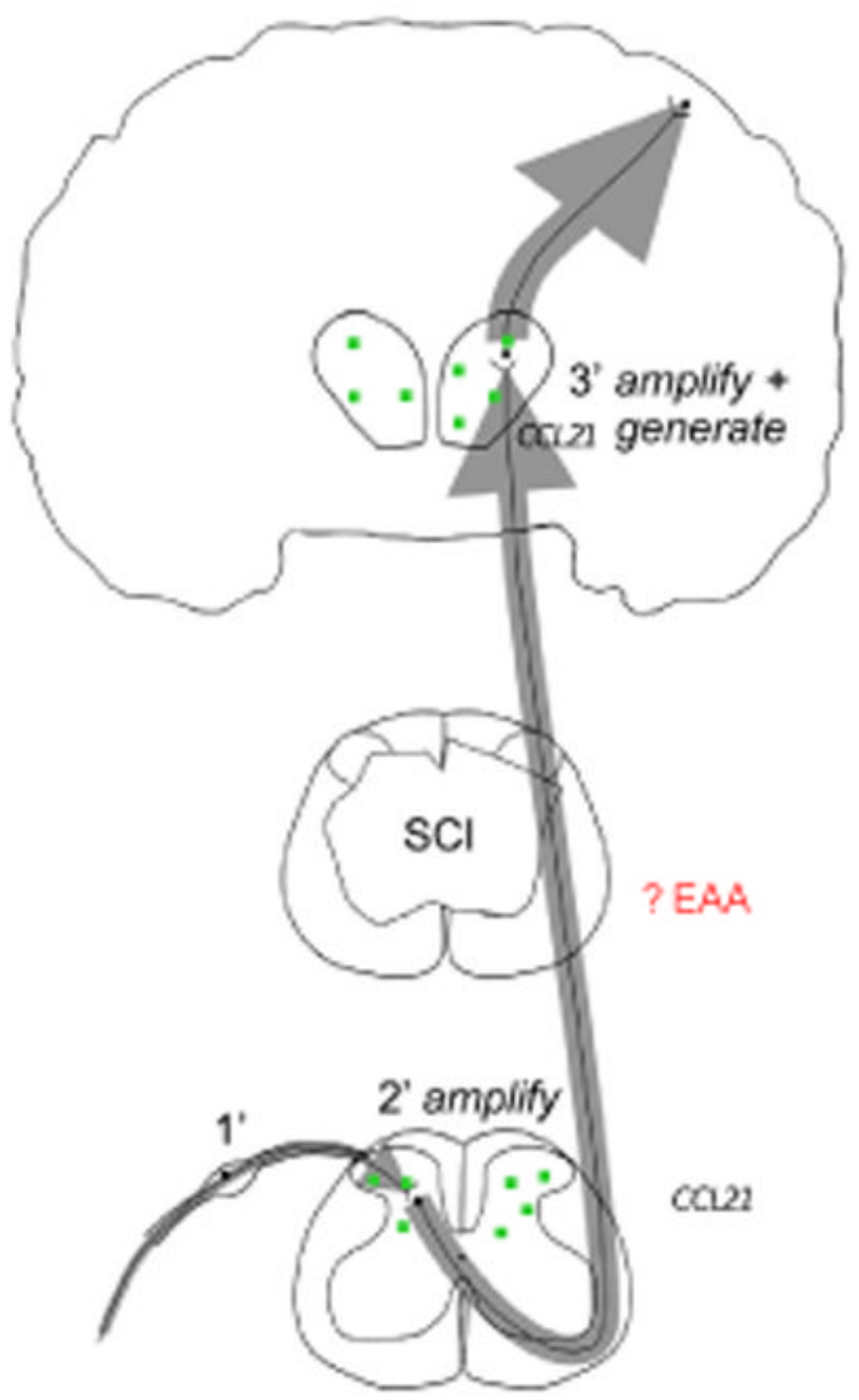

Figure 1.

A massive release of glutamate at the SCI lesion epicenter triggers upregulation of the chemokine CCL21 both at the site of injury and in cell bodies of STT neurons whose axons have been exposed to high concentrations of glutamate. CCL21 is then released at remote sites from the injury activating microglia, thatcontributeto neuronal hyperexcitability in the spinal cord dorsal horn and thalamus. Abnormal amplification and generation of nociceptive signals at these levels contributes to chronic pain after injury. 


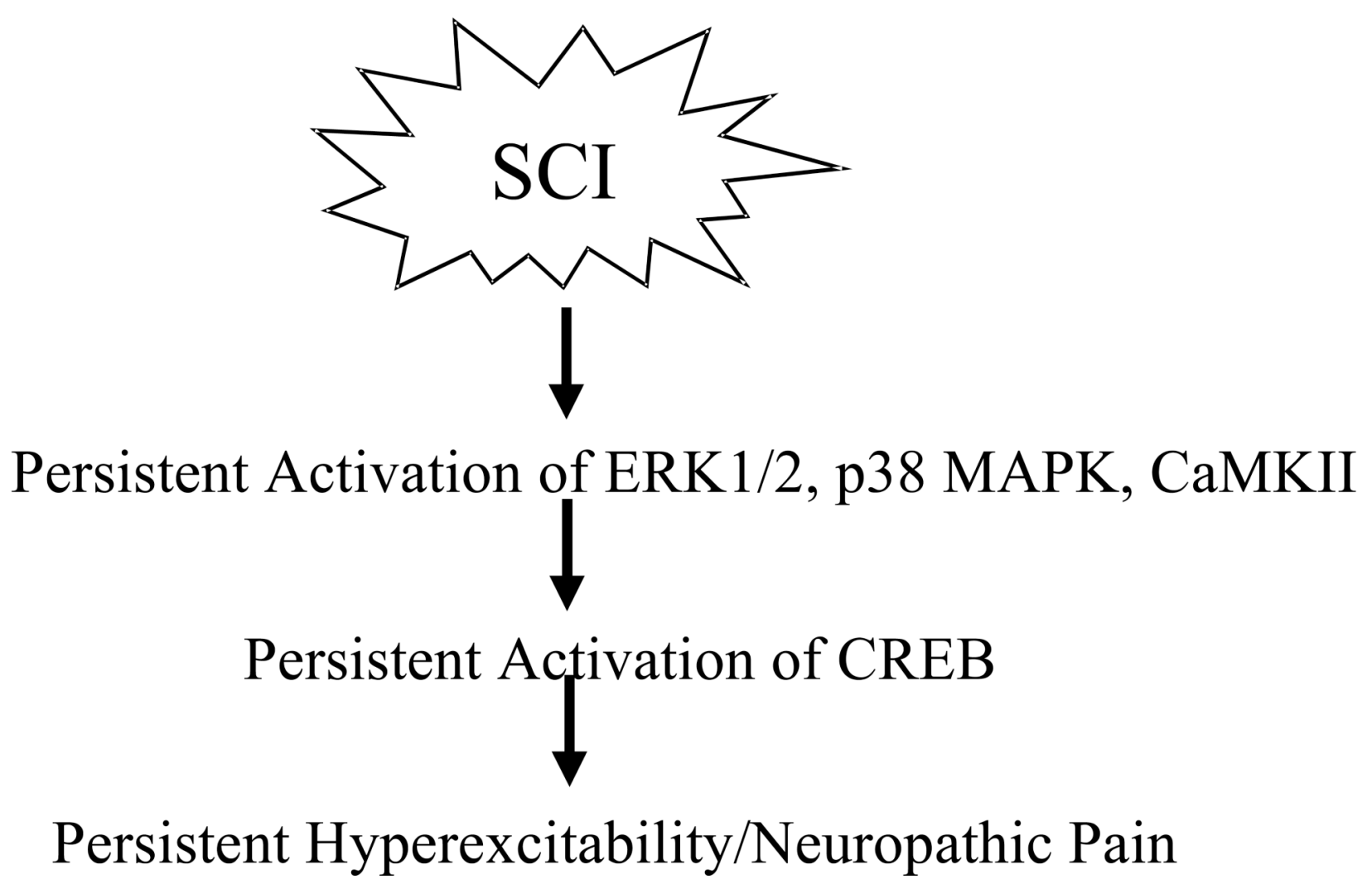

Figure 2.

SCI leads to persistent activation of intracellular signaling kinases such as ERK 1/2, p38 mitogen activated protein kinases (MAPK) and calcium calmodulin kinases (CaMKII) that lead to persistent activation of CREB, a transcription factor that contributes directly to factors that phosphorylated NR1 subunits of the NMDA channel, leading to persistent hyperexcitability of spinal and supraspinal neurons. This provides the substrate for persistent or neuropathic pain. 


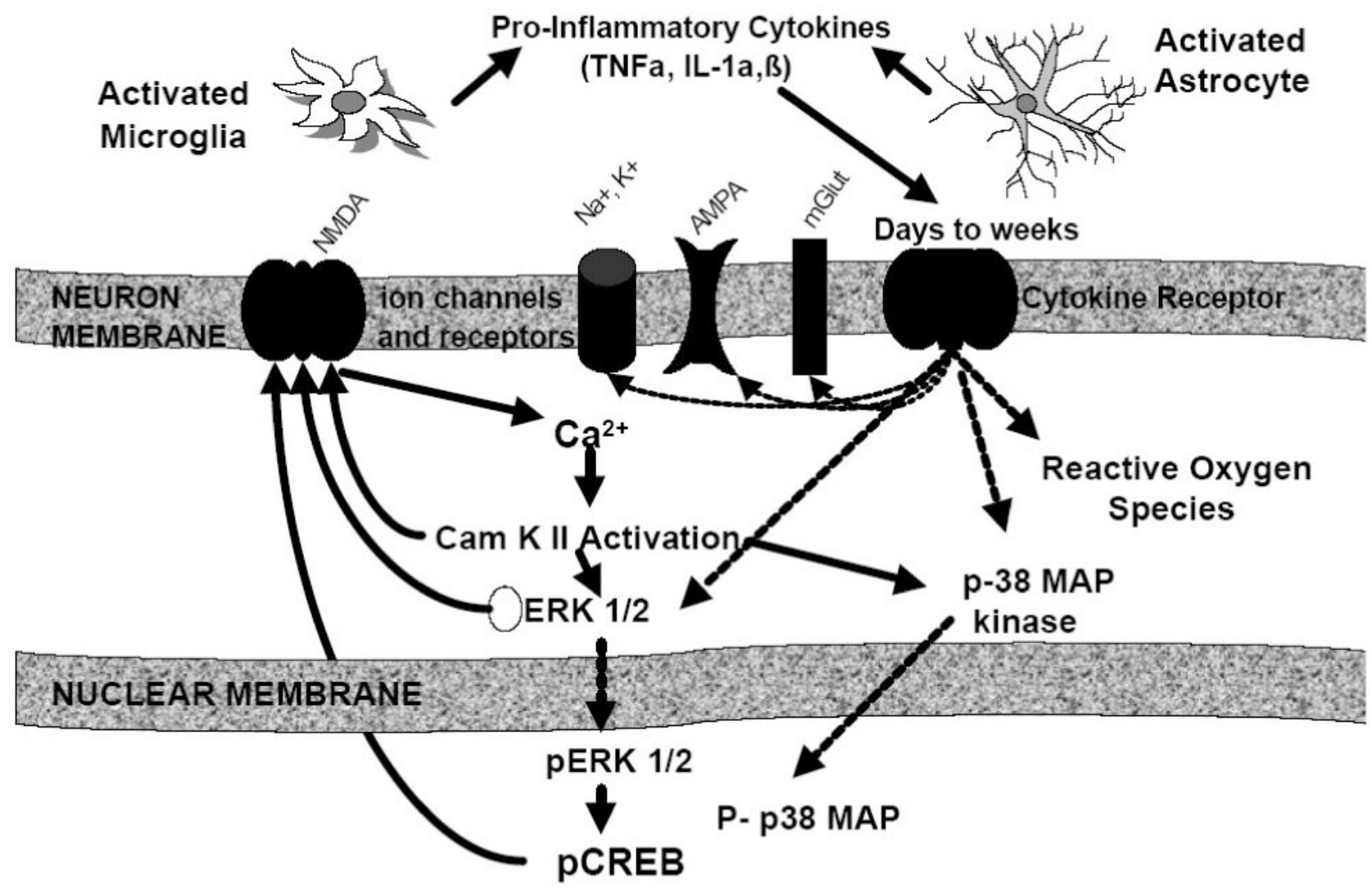

Figure 3.

In the chronic SCI neuron, persistent activation of microglia and astrocytes contribute to production of proinflammatory cytokines, reactive oxygen species (ROS), ATP, excitatory amino acids, nitric oxide (NO) and other factors. Many of these factors, such as specific proinflammatory cytokines (ex. TNF $\alpha$; IL-1 $\alpha, \beta$ ) trigger cytokine receptor mediated intracellular pathways in neurons that result in continued activation of NMDA, AMPA and metabotropic glutamate channels as well as cation channels. Thus, neuronal membranes remain hyperexcitable such that incoming sensory subthreshold input (ie. non-noxious stimuli) is now input into a "reset" circuit leading to altered sensory interpretations (ie. non-noxious stimuli becomes noxious: allodynia) or chronic pain. 